\title{
PENGARUH UPAH TERHADAP MOTIVASI KERJA KARYAWAN
}

(Studi Kasus Pada Karyawan UD. Pakem Sari, Desa Sumberpakem, Kecamatan Sumberjambe, Kabupaten Jember)

\author{
M. Dilif Lailun Ni'am ${ }^{1}$, Bambang Suyadi ${ }^{1}$, Hety Mustika Ani ${ }^{1}$ \\ ${ }^{1}$ Program Studi Pendidikan Ekonomi, Fakultas Keguruan dan Ilmu Pendidikan, Universitas Jember \\ E-mail : 140210301018@students.unej.ac.id
}

\begin{abstract}
Abstrak
Penelitian ini dilakukan untuk mengetahui pengaruh yang signifikan antara upah (upah pokok, sistem upah, kebijakan pemberian upah dan upah total) terhadap motivasi kerja karyawan (semangat kerja dan gairah kerja) UD. Pakem Sari, Desa Sumberpakem, Kecamatan Sumberjambe, Kabupaten Jember. Adapun penentuan lokasi dalam penelitian ini menggunakan metode purposive area dan menjadikan semua populasi sebagai responden karena jumlah populasi relatif sedikit yaitu sebanyak 35 karyawan. Metode analisis data yang digunakan adalah analisis inferensial menggunakan regresi linier sederhana. Hasil penelitian menunjukkan bahwa upah memiliki pengaruh yang signifikan terhadap motivasi kerja karyawan UD. Pakem Sari, Sumberjambe, Jember. Hasil penelitian menunjukkan bahwa analisis regresi linier sederhana menghasilkan persamaan $Y=2,211+0,205 X$ dengan nilai $\mathrm{R}_{\text {Square }}$ sebesar 0,564 , nilai $\mathrm{F}_{\text {hitung }}$ sebesar 42,631, $F_{\text {tabel }}$ sebesar 4,14 pada taraf signifikansi 0,05 dengan kriteria pengujian yaitu jika $F_{\text {hitung }}>F_{\text {tabel }}$ maka Ho ditolak. Hal tersebut menunjukkan bahwa upah memiliki pengaruh yang signifikan terhadap motivasi kerja karyawan UD. Pakem Sari, Sumberjambe, Jember dengan besaran pengaruh sebesar 56,4\%, sedangkan sisanya 43,6\% dipengaruhi oleh variabel lain yang tidak diteliti. Saran yang dapat diberikan oleh peneliti kepada manajemen UD. Pakem Sari, Sumberjambe Jember, yaitu diharapkan untuk selalu adil dan benar dalam memberikan upah kepada karyawannya serta meningkatkan strategi dalam pemberian upah agar motivasi kerja karyawan juga meningkat.
\end{abstract}

Kata Kunci: Upah, Motivasi kerja, Karyawan

\section{PENDAHULUAN}

Perusahaan dan sumber daya manusia merupakan dua kelompok yang saling mendukung dan memiliki keterkaitan. Oleh sebab itu, diperlukan suatu kerjasama yang saling menguntungkan antara satu dengan yang lainnya. Hubungannya yaitu sumber daya manusia dapat menjadi modal utama dalam menunjang keberhasilan perusahaan apabila dikelola dengan baik, dimana pengelolaan tersebut dimulai ketika mereka belum dipekerjakan sampai dengan dipekerjakan.

Sumber daya manusia memegang peran penting dalam sebuah perusahaan, sebab faktor manusia (karyawan) merupakan penggerak utama disetiap kegiatan yang ada didalam perusahaan, karena karyawan yang melakukan kegiatan perusahaan mulai dari merencanakan, melaksanakan, hingga mengendalikan setiap kegiatan dan aktivitas perusahaan. Karyawan merupakan sumber daya yang penting bagi perusahaan, karena memiliki bakat, tenaga dan kreativitas yang sangat dibutuhkan oleh perusahaan untuk mencapai tujuannya.

Tujuan perusahaan dapat dicapai dengan lancar, jika memiliki karyawan yang profesional dan dikelola dengan baik. Oleh karena itu, untuk mencapai hasil yang efektif, maka para karyawan tersebut haruslah diberi rangsangan agar dalam melaksanakan pekerjaannya dapat lebih baik dan bersemangat. Hal yang dimaksudkan ialah masalah upah yang diberikan perusahaan kepada karyawan, sebab karyawan juga mempunyai berbagai macam kebutuhan yang ingin dipenuhinya dan keinginan yang berbeda dari masing-masing karyawan. Keinginan untuk memenuhi kebutuhan inilah yang dipandang sebagai pendorong atau penggerak bagi seorang karyawan untuk melakukan sesuatu, termasuk melakukan pekerjaan atau bekerja.

Perusahaan yang memiliki karyawan yang bisa terdorong dari hasil pekerjaannya biasanya dapat dijumpai pada perusahaan yang bergerak dibidang kerajinan, dimana besarnya upah yang diberikan kepada masing-masing karyawan adalah berdasarkan banyaknya produk yang dibuat karyawan. UD. Pakem Sari merupakan sebuah usaha dagang yang bergerak dalam bidang kerajinan batik yang 
bermotif labako khas Kota Jember. Usaha dagang ini beralamat di jalan Raung Desa Sumberpakem, Kecamatan Sumberjambe, Kabupaten Jember yang sudah berdiri sejak tahun 1935 dan didirikan secara turun temurun, namun pada saat itu masih merupakan home industry. Pada tahun 1984 home industry ini sudah menjadi sebuah UD (usaha dagang) yang resmi dan sudah terdaftar dalam DISPERINDAG (Dinas Perindustrian dan Perdagangan) Kota Jember.

Berdasarkan hasil observasi awal dengan pemilik UD. Pakem Sari menunjukkan bahwa standar pengupahan sudah sama dengan pengusaha kerajinan batik pada umumnya, yaitu besar kecilnya upah yang diberikan kepada karyawan berdasarkan jumlah unit kain batik yang dihasilkan karyawan, artinya karyawan akan mendapatkan upah yang sesuai dari banyaknya unit produk yang dihasilkan oleh karyawan itu sendiri. Dapat dikatakan bahwa sistem pengupahan yang diterapkan oleh UD. Pakem Sari Sumberjambe Jember adalah upah sistem hasil (output), yaitu besarnya upah ditetapkan atas satuan unit yang dihasilkan para karyawan, yakni perpotong kain batik. Biasanya perpotong kain batik yang dihasilkan oleh karyawan berkisar antara 2 meter sampai 2,10 meter.

Pemberian upah yang adil dan benar kepada karyawan merupakan hal yang sangat penting bagi perusahaan dan karyawan. Perusahaan akan mendapatkan karyawan yang bersedia bekerja dan menjalankan tugas-tugasnya dengan baik, sedangkan karyawan merasa pemberian upah tersebut sebagai penghargaan atas kerja yang telah dilaksanakan. Upah sendiri bisa dikatakan sebagai imbalan langsung yang berupa uang dan diberikan kepada karyawan atas hasil kerjanya yang dapat diukur dengan satuan tertentu (jumlah unit barang yang dihasilkan atau masa atas jasa pekerjaan yang diserahkan). Sementara upah di UD. Pakem Sari dapat dilihat dari tiga hal yaitu upah pokok, bentuk dan cara pengupahan serta skala pengupahan.

Upah pokok sendiri merupakan imbalan uang secara langsung dari hasil perlembar kain batik yang dibuat oleh karyawan. Bentuk pengupahan yang diterapkan oleh UD. Pakem Sari adalah sistem hasil dengan cara pengupahan dibayar langsung setelah produk selesai dibuat. Sedangkan skala upah disini yaitu kesetaran besaran upah kepada masing-masing karyawan untuk pekerjaan yang sama. Jika ketiga hal tersebut diberikan secara benar kepada karyawan, maka tujuan perusahaan akan cepat tercapai.

Tujuan pemberian upah oleh perusahaan adalah untuk ikatan kerja sama, kepuasan kerja, motivasi kerja dan disipilin. Salah satunya yaitu untuk memotivasi karyawan dalam bekerja, dimana pemberian upah yang adil dan benar akan meningkatkan motivasi kerja karyawan sehingga merangsang karyawan untuk bekerja dengan giat. Sebaliknya, jika pemberian upah tidak benar, maka dapat menurunkan motivasi kerja karyawan. Seperti yang dikatakan oleh Hasibuan (2016:103) bahwa, "setiap manusia/karyawan mengharapkan kompensasi (gaji/upah) dari prestasi yang diberikannya dalam mendukung faktor motivasi kerja".

Motivasi kerja merupakan sesuatu yang pokok yang menjadi dorongan bagi seseorang untuk bekerja. Adapun alat motivasi kerja yang digunakan oleh UD. Pakem Sari dalam membayar para karyawannya adalah berupa uang dan barang, dimana uang adalah sebagai upah pokok bekerja dari setiap perlembar kain batik yang dibuat karyawan dan barang yang diberikan sebagai bentuk tunjangan hari raya dalam setiap tahunnya. Dalam memotivasi karyawan, ada dua hal yang harus diperhatikan oleh pemilik perusahaan agar tujuan pemberian upah ini bisa lancar, yaitu faktor eksternal dan faktor internal.

Faktor eksternal merupakan pembentukan motivasi kerja karyawan yang berasal dari luar diri karyawan atau juga disebut dengan faktor pemeliharaan yang terdiri dari hubungan antarpribadi dan tunjangan. Maksud dari hubungan antarpribadi adalah hubungan ketentraman baik antara karyawan dengan pemilik perusahaan ataupun sesama karyawan. Sedangkan faktor internal merupakan pembentukan motivasi kerja karyawan yang berasal dari luar diri karyawan atau disebut dengan faktor motivasional yang terdiri dari pengakuan, pekerjaan itu sendiri dan pengembangan potensi individu.

Proses pengaplikasian dalam memotivasi karyawan UD. Pakem Sari sendiri dipengaruhi oleh berbagai faktor, sehingga perusahaan terkadang mengalami kesulitan dalam upaya meningkatkan motivasi kerja karyawannya, seperti yang diungkap Hasibuan (2016:93) yang mengatakan "memotivasi ini sangat sulit karena pimpinan sulit untuk mengetahui kebutuhan (needs) dan keinginan (wants) yang diperlukan bawahan dari hasil pekerjaannya".

Salah satu faktor yang mempengaruhi motivasi kerja karyawan UD. Pakem Sari dalam meningkatkan hasil unit pekerjaannya yaitu pengupahan. Hasil perlembar kain batik dan motivasi kerja karyawan yang 
meningkat merupakan harapan semua pihak, namun kenyataan di lapangan masih menunjukkan pengupahan yang diberikan kepada karyawan masih kurang lancar. Hal tersebut dapat terlihat dari karyawan yang bekerja tidak maksimal, dimana masih ada beberapa karyawan yang tidak masuk bekerja dan tidak segera menyelesaikan pekerjaannya sehingga stok kain batik yang siap dijual menjadi sangat terbatas. Berdasarkan uraian tersebut dan pentingnya upah serta motivasi kerja karyawan dalam meningkatkan hasil unit kain batik mendorong peneliti untuk melakukan penelitian lebih lanjut dengan judul "Pengaruh Upah terhadap Motivasi Kerja Karyawan (Studi Kasus pada Karyawan UD. Pakem Sari Desa Sumberpakem, Kecamatan Sumberjambe, Kabupaten Jember)".

\section{METODE PENELITIAN}

Penelitian ini dilakukan dengan metode kuantitatif menggunakan analisis regresi linier sederhana. Adapun metode penentuan lokasi dalam penelitian menggunakan purposive area dan menggunakan semua populasi sebagai responden penelitian karena jumlah populasi relatif sedikit, yakni sebanyak 35 karyawan. Metode pengumpulan data menggunakan metode angket, wawancara dan dokumen. Angket yang sudah terkumpul selanjutnya dilakukan uji instrumen yaitu uji validitas dan uji reliabilitas, kemudian dianalisis dengan menggunakan analisis inferensial yang terdiri dari garis regresi linier sederhana, varian garis regresi, uji $\mathrm{F}$, efektivitas garis regresi dan standart error of estimate, untuk memudahkan perhitungan analisis data maka peneliti menggunakan bantuan program SPSS 22.0 for windows.

\section{HASIL DAN PEMBAHASAN}

\section{Hasil Penelitian}

Hasil perhitungan analisis regresi linier sederhana dengan menggunakan program SPSS 22.0 for windows adalah sebagai berikut:

Tabel 1. Hasil analisis regresi linier sederhana

Coefficients $^{\mathbf{a}}$

\begin{tabular}{|c|c|c|c|c|c|c|}
\hline \multirow{2}{*}{\multicolumn{2}{|c|}{ Model }} & \multicolumn{2}{|c|}{ Unstandardized Coefficients } & $\begin{array}{l}\text { Standardized } \\
\text { Coefficients }\end{array}$ & \multirow[b]{2}{*}{$\mathrm{t}$} & \multirow[b]{2}{*}{ Sig. } \\
\hline & & $\mathrm{B}$ & Std. Error & Beta & & \\
\hline & (Constant) & 2,211 & 1,286 & & 1,718 & ,095 \\
\hline & Upah & 205 & ,031 & ,751 & 6,529 & ,000 \\
\hline
\end{tabular}

a. Dependent Variable: Motivasi Kerja

Berdasarkan data di atas, maka persamaan regresi sederhana yang diperoleh dalam penelitian ini adalah sebagai berikut:

$$
\hat{\mathbf{Y}}=1,974+1,476 \mathrm{X}
$$

Adapun hasil perhitungan untuk analisis varian garis regresi adalah sebagai berikut:

Tabel 2. Hasil interpretasi model summary

Model Summary

\begin{tabular}{|l|r|r|r|r|}
\hline Model & $\mathrm{R}$ & R Square & \multicolumn{1}{|c|}{$\begin{array}{c}\text { Adjusted R } \\
\text { Square }\end{array}$} & $\begin{array}{c}\text { Std. Error of the } \\
\text { Estimate }\end{array}$ \\
\hline 1 &, $751^{\mathrm{a}}$ &, 564 &, 550 &, 732 \\
\hline
\end{tabular}

a. Predictors: (Constant), Upah 
Berdasarkan hasil data yang didapatkan seperti yang terlihat pada tabel di atas, maka diketahui besarnya nilai koefisien korelasi adalah 0,751. Koefisien korelasi sebesar 0,751 tersebut menunjukkan bahwa hubungan antara variabel (X) upah terhadap variabel (Y) motivasi kerja karyawan UD. Pakem Sari Sumberjambe, Jember dikategorikan mempunyai hubungan yang kuat.

Hasil $R$ Square seperti yang terlihat pada tabel 2 sebesar 0,564, sehingga hasil akhir setelah dimasukkan ke dalam rumus koefisien determinasi $\left(\mathrm{R}^{2}\right)$ adalah sebagai berikut:

$$
R \text { Square } x 100 \%=0,564 \times 100 \%=\mathbf{5 6 , 4 \%}
$$

Hal ini menunjukkan bahwa besarnya persentase pengaruh upah terhadap motivasi kerja karyawan UD. Pakem Sari, Sumberjambe, Jember sebesar 56,4\%. Adapun perhitungan dari Uji F, diketahui nilai $\mathrm{F}_{\text {hitung }}$ sebagai berikut:

Tabel 3. Hasil uji F

ANOVA $^{\mathrm{a}}$

\begin{tabular}{|ll|r|r|r|r|r|}
\hline Model & & Sum of Squares & Df & Mean Square & F & Sig. \\
\hline 1 & Regression & 22,869 & 1 & 22,869 & 42,631 &, $000^{\mathrm{b}}$ \\
& Residual & 17,702 & 33 &, 536 & & \\
& Total & 40,571 & 34 & & & \\
\hline
\end{tabular}

a. Dependent Variable: Motivasi Kerja

b. Predictors: (Constant), Upah

Berdasarkan data di atas, diketahui bahwa nilai $\mathrm{F}_{\text {hitung }}=42,631$ lebih besar dari $\mathrm{F}_{\text {tabel }}=4,14$ dengan tingkat signifikansi 0,000 lebih kecil dari $a=0,05$. Hal ini menunjukkan bahwa variabel upah memiliki pengaruh yang signifikan terhadap motivasi kerja karyawan UD. Pakem Sari, Sumberjambe, Jember.

\section{Pembahasan}

Hasil analisis data telah menunjukkan bahwa karyawan telah menilai bahwa upah pokok, sistem upah, kebijakan pemberian upah dan upah total yang diberikan oleh UD. Pakem Sari dapat dikatakan sudah sesuai dengan harapan karyawan dalam mendukung motivasi kerja mereka, sehingga upah memiliki pengaruh yang signifikan terhadap peningkatan motivasi kerja karyawan.

Setiap perusahaan atau organisasi pasti memiliki tujuan yang ingin dicapai, dalam mencapai tujuan tersebut diperlukan karyawan yang memiliki motivasi tinggi dalam bekerja, oleh karena itu pemimpin perusahaan harus bisa memotivasi karyawannya agar tujuan tersebut bisa tercapai dengan lancar. Sementara itu, pemilik UD. Pakem Sari Sumberjambe Jember sangat memahami bagaimana memotivasi karyawannya dalam bekerja, sehingga mudah dalam membentuk motivasi kerja karyawannya. Hal tersebut sesuai dengan pendapat Arifin, Amirullah dan Khalikussabir (2017:63) yang mengatakan bahwa "untuk menggerakkan manusia agar sesuai dengan yang dikehendaki organisasi, maka haruslah dipahami motivasi manusia yang bekerja dalam organisasi tersebut, karena motivasi inilah yang menentukan perilaku orang-orang bekerja”.

Hasil unit batik yang dibuat karyawan dalam setiap minggunya berbeda-beda, mulai dari sembilan lembar sampai dua puluh satu lembar kain batik. Minggu pertama bulan Mei 2018, masing-masing karyawan membuat batik tulis yang sudah dipesan oleh pelanggan, dimana yang dipesan hanya batik tulis jadi semua 
karyawan diarahkan untuk membuat batik tulis. Adapun upah yang diterima karyawan pada waktu tersebut berbeda-beda yakni sesuai dengan upah sistem hasil, dimana besaran upah yang diterima karyawan sesuai dengan jumlah unit yang dihasilkan karyawan. Hal tersebut sesuai dengan pendapat Afandi (2018:194) yang mengatakan bahwa "dalam sistem hasil, besarnya upah ditetapkan atas kesauan unit yang dihasilkan pekerja, seperti perpotong, meter, liter dan kilogram".

Sistem pengupahan sudah dinilai sangat baik dan sesuai oleh sebagian karyawan, kesetaraan upah yang sesuai dan tingkat upah yang sangat baik. Selain itu, karyawan juga menilai upah pokok yang sangat memuaskan serta upah total yang sudah mencukupi kebutuhan karyawan. Hal tersebut tentu sudah membuat para karyawan merasa nyaman bekerja di UD. Pakem Sari ini. Karyawan juga merasakan sistem pemberian upah yang diberikan oleh UD. Pakem Sari berjalan dengan lancar, karena upah langsung diberikan dalam jangka waktu dua sampai dengan empat hari setelah kain batik selesai dibuat.

Motivasi kerja karyawan UD. Pakem Sari bisa dikatakan baik sebab sistem pengupahan yang berupa upah satuan lembar kain batik dapat mendorong karyawan untuk bekerja lebih baik. Jadi, agar mendapatkan upah yang tinggi maka para karyawan UD. Pakem Sari termotivasi untuk membuat kain batik dengan jumlah yang banyak pula, karena kebanyakan karyawan bekerja hanya untuk mendapatkan upah yang banyak dan sesuai dengan hasil satuan lembar kain batik yang dibuat oleh mereka. Hal tersebut juga sudah sesuai dengan pendapat Kasmir (2017:230) yang mengatakan bahwa "salah satu tujuan utama dari seseorang untuk bekerja adalah karena ingin memperoleh sejumlah penghasilan" dan didukung oleh pendapat Hasibuan (2016:107) yang mengatakan bahwa "seseorang berperilaku/bekerja adalah untuk dapat memenuhi kebutuhan-kebutuhan (materiil dan non-materiil) yang akan memberikan kepuasan baginya dalam mendukung motivasi kerjanya", sedangkan maksud materiil dan non-materiil adalah kebutuhan akan penghasilan yang berupa uang dan bukan uang.

Sistem pengupahan yang diterapkan oleh UD. Pakem Sari juga sudah dinilai konsisten oleh para karyawan. Karyawan menilai sistem pengupahan disini sudah sesuai dengan tingkat inflasi yang ada pada saat ini, serta UD. Pakem Sari juga dinilai konsisten dalam pemberian upah yang tinggi untuk pekerjaan yang memerlukan tenaga lebih. Hal tersebut sesuai dengan pendapat Arifin, Amirullah dan Khalikussabir (2017:80) yang mengatakan bahwa "sistem pemberian upah yang baik harus konsisten, sehingga pekerja yang punya nilai lebih tinggi dengan sendirinya menghasilkan gaji/upah yang lebih tinggi pula dan konsisten dengan lingkungan ekonomi sehingga selalu dapat mempertimbangkan inflasi maupun perubahan situasi ekonomi”.

Faktor lainnya yang mempengaruhi motivasi kerja karyawan adalah kebijakan pemberian upah. Sesuai dengan penilaian para karyawan, kebijakan pemberian upah yang diterapkan oleh UD. Pakem Sari juga dinilai baik. Artinya dalam memberikan upah, UD. Pakem Sari sudah memberikan keadilan kepada seluruh karyawannya. Arifin, Amirullah dan Khalikussabir (2017:81-82) yang mengatakan bahwa "salah satu faktor motivasional terbesar ditempat kerja pada saat ini adalah apakah karyawan merasa mereka diberi kompensasi yang adil dibandingkan karyawan lain di tempat mereka bekerja". Selain itu, karyawan juga menilai tingkat besaran upah sudah sesuai dengan perusahaan lainnya yang sudah ditetapkan oleh peraturan yang berlaku serta upah yang diberikan sudah setara antar sesama karyawan. Hal tersebut, sesuai dengan pendapat Kasmir (2017:234) yang mengatakan bahwa "kebijakan pemberian kompensasi yang berupa gaji/upah haruslah memberikan rasa keadilan bagi seluruh karyawan. Artinya dalam menentukan besarnya gaji/upah haruslah mengikuti aturan yang telah ditetapkan dan harus sama kepada setiap orang sesuai usahanya dan kemampuan yang dimilikinya".

Upah pokok dari satu lembar kain batik yang diterima oleh karyawan UD. Pakem Sari berbeda-beda, tergantung dari jenis batik dan banyaknya motif yang ada pada kain batik. Besaran upah untuk jenis batik tulis dengan motif yang banyak adalah sebesar Rp 50.000, sedangkan untuk motif yang sedikit besaran upah adalah sebesar Rp 40.000. Besaran upah untuk jenis batik semua tulis dengan motif yang banyak adalah sebesar Rp 35.000, sedangkan untuk motif yang sedikit adalah sebesar Rp 25.000. Jenis batik cap yang dihasilkan karyawan dengan motif yang banyak maka akan diberi upah sebesar Rp 24.000, sedangkan untuk motif yang sedikit besaran upah adalah sebesar Rp 20.000. Pemberian upah tersebut sudah dikatakan adil karena upah yang diberikan sesuai dengan kerja keras karyawan. Hal tersebut sesuai dengan pendapat Hasibuan (2016:121) yang 
mengatakan bahwa "pemberian gaji/upah dan hukuman harus berdasarkan atas penilaian yang objektif dan adil".

Upah yang dihasilkan dalam setiap minggunya juga berbeda, mulai dari Rp 50.000 sampai dengan lebih dari Rp 250.000. Hal tersebut tergantung dari seberapa banyak kain batik yang dihasilkan karyawan serta tetap mengacu pada jenis batik dan jumlah motif yang dihasilkan, sedangkan kebanyakan karyawan menerima upah sebesar Rp 200.000 - Rp 245.000 dalam setiap minggunya. Begitu pula dengan upah yang diterima dalam satu bulan, kebanyakan karyawan menerima upah sebanyak Rp Rp 750.000 - Rp 950.000. Dari sekian banyak karyawan menilai bahwa upah pokok yang diberikan oleh UD. Pakem sari itu memuaskan, dimana kepuasan inilah yang bisa terus mendorong karyawan untuk bekerja lebih giat lagi. Hal tersebut sesuai dengan pendapat Hasibuan (2016:95) yang mengatakan bahwa "rangsangan (materiil dan nonmateriil) ini akan menciptakan motif dan motivasi yang mendorong orang bekerja (beraktivitas) untuk memperoleh kebutuhan dari hasil kerjanya". Upah yang diterima karyawan berdasarkan perlembar kain batik, perminggu dan perbulan merupakan faktor yang penting dalam proses meningkatkan motivasi kerja karyawan. Hal tersebut sesuai dengan pendapat Arifin, Amirullah dan Khalikussabir (2017:80) yang mengatakan bahwa "gaji/upah pokok dalam banyak kasus tetap merupakan unsur paling penting. Apabila jumlah total gaji/upah bruto benar-benar dikaitkan dengan prestasi, gaji/upah bruto itupun dapat menjadi motivator yang positif".

Faktor selanjutnya yang mempengaruhi motivasi kerja karyawan UD. Pakem Sari Sumberjambe Jember ialah upah keseluruhan atau upah total, dimana upah total disini dinilai sudah bisa mencukupi kebutuhan karyawan. Dalam salah satu teori, hal tersebut sesuai dengan pendapat Arifin, Amirullah dan Khalikussabir (2017:67) yang mengatakan bahwa "motivasi para pekerja hanya dipandang dari sudut pemenuhan kebutuhan fisik/biologi saja. Kebutuhan biologis tersebut dipenuhi melalui insentif atau gaji (upah) yang diberikan, berupa uang atau barang sebagai imbalan atas prestasi yang telah mereka berikan".

Kontrisbusi pengaruh upah terhadap motivasi kerja karyawan UD. Pakem Sari Sumberjambe Jember adalah sebesar 56,4\%, kontribusi ini (upah) tidak besar, sebab masih banyak faktor-faktor lain yang dapat membuat karyawan merasa terdorong untuk bekerja lebih giat. Adapun faktor-faktor tersebut adalah pengakuan, penghargaan, kebutuhan karyawan, hubungan kerja, prestasi kerja, lingkungan kerja, jaminan pekerjaan serta status dan tanggung jawab. Hal tersebut sesuai dengan pendapat Mulyadi (2018:54-55) yang mengatakan bahwa "motivasi seseorang sangat dipengaruhi dua faktor, pertama faktor internal yang terdiri dari persepsi individu mengenai diri sendiri, harga diri dan prestasi, harapan, kebutuhan dan kepuasan kerja. Kedua faktor eksternal yang terdiri dari jenis dan sifat pekerjaan, kelompok kerja dimana individu bergabung, situasi lingkungan pada umumnya dan sistem imbalan yang diterima". Teori tersebut juga didukung oleh pendapat Sutrisno (2016:116120) yang mengatakan bahwa "motivasi sebagai proses psikologis dalam diri seseorang akan di pengaruhi oleh beberapa faktor. Faktor-faktor tersebut dapat dibedakan atas faktor intern dan ekstern yang berasal dari karyawan. Faktor intern terdiri dari keinginan untuk dapat hidup, keinginan untuk dapat memiliki, keinginan untuk memperoleh penghargaan, keinginan untuk memperoleh pengakuan dan keinginan untuk berkuasa. Faktor ekstern terdiri dari kondisi lingkungan kerja, kompensasi yang memadai, supervisi yang baik, adanya jaminan pekerjaan, status dan tanggung jawab serta peraturan yang fleksibel”.

UD. Pakem Sari telah berhasil menjaga motivasi kerja karyawan tetap bertahan dengan menjaga upah yang diberikan tetap wajar dan adil serta juga telah benar dalam memilih sistem upah yang diberikan untuk meningkatkan motivasi kerja karyawannya. Hal tersebut sesuai pendapat Arifin, Amirullah dan Khalikussabir (2017:74) yang mengatakan bahwa "faktor utama dalam motivasi pekerjaan adalah evaluasi individu atas keadilan dari penghargaan yang diterima. Artinya keadilan disini ialah perbandingan usaha atau keterampilan dan balas jasa (gaji, upah dan promosi) dari yang mereka kerjakan". Teori lain yang mendukung hasil penelitian ini juga diungkapkan oleh Nawawi (2001:372) bahwa "pemberian upah merupakan motivasi kerja yang penting dalam mewujudkan pekerjaan yang produktif dan berkualitas (efektif dan efisien) bagi para pekerja di bidang kerja masing-masing". Oleh karena itu, hipotesis dalam penelitian ini yang menduga bahwa ada pengaruh yang signifikan antara upah terhadap motivasi kerja karyawan UD. Pakem Sari Sumberjambe Jember dapat diterima sehingga tujuan penelitian ini telah tercapai. 


\section{PENUTUP}

\section{Kesimpulan}

Berdasarkan hasil penelitian dan pembahasan yang telah dilakukan, maka dapat diambil kesimpulan bahwa upah memiliki pengaruh yang signifikan terhadap motivasi kerja karyawan UD. Pakem Sari Sumberjambe Jember. Tingkat besaran upah yang diberikan kepada karyawan adalah berdasarkan jenis batik dan jumlah motif batik, dimana hal tersebut akan membuat karyawan termotivasi untuk menghasilkan kain batik dengan perolehan upah yang besar agar kebutuhan dan keinginan masing-masing karyawan terpenuhi. Adapun kontribusi variabel upah terhadap variabel motivasi kerja karyawan adalah sebesar 56,4\% dan sisanya 43,6\% dipengaruhi oleh variabel lain yang tidak diteliti dalam penelitian ini seperti pengakuan, penghargaan, kebutuhan karyawan, hubungan kerja, prestasi kerja, lingkungan kerja, jaminan pekerjaan serta status dan tanggung jawab karyawan.

\section{Saran}

Berdasarkan kesimpulan dari penelitian ini, maka peneliti dapat memberikan saran kepada beberapa pihak antara lain:

1. Bagi UD. Pakem Sari, diharapkan untuk selalu adil dan benar dalam memberikan upah kepada karyawannya, serta meningkatkan strategi dalam pemberian upah agar karyawan termotivasi untuk bekerja lebih giat.

2. Bagi peneliti lain, untuk ikut mempertimbangkan variabel bebas lain yang tidak diteliti pada penelitian ini, seperti pengakuan, penghargaan, kebutuhan karyawan, hubungan kerja, prestasi kerja, lingkungan kerja, jaminan pekerjaan serta status dan tanggung jawab karyawan.

\section{DAFTAR PUSTAKA}

Afandi, P. 2018. Manajemen Sumber Daya Manusia (Teori, Konsep dan Indikator). Pekanbaru: Zanafa Publishing.

Arifin R., Amirullah, \& Khalikussabir. 2017. Budaya dan perilaku organisasi. Malang: Empat Dua Intrans Publishing.

Hasibuan, M. S. P., 2016. Organisasi dan Motivasi (Dasar Peningkatan Produktivitas). Jakarta: PT. Bumi Aksara.

Kasmir. 2017. Manajemen Sumber Daya Manusia (Teori dan Praktik). Depok: Rajawali Pers.

Mulyadi, D. 2018. Perilaku Organisasi dan Kepemimpinan Pelayanan. Bandung: CV. Alfabeta.

Nawawi, H. Hadari. 2001. Manajemen Sumber Daya Manusia untuk Bisnis yang Kompetitif. Yogyakarta: Gadjah Mada University Press

Sutrisno, E. 2016. Manajemen Sumber Daya Manusia. Jakarta: Prenada Media Group. 